\title{
CONTEMPORARY TRADITIONAL CLOTHING IN MARAMUREŞ
}

\author{
Anamaria Iuga
}

\begin{abstract}
The article is concerned with presenting the meanings and the dynamic of contemporary festive traditional garments in the region of Maramureş (northern Romania). Based on an empirical approach, it analyses the morphology of local clothing, describing the two types of costumes considered as traditional today: an older type, with all the component pieces homemade, and a newer type, using industrial fabric, bought in the local markets. As clothes bear meanings, and people create and use them in a variety of contexts, the study is exploring, also, the different meanings that garments acquire when used, such as how they contribute to expressing the public self of a person, but also how they are valued and presented as important local heritage.
\end{abstract}

Keywords: dynamic of tradition, festive clothing, Maramureş, Romania, traditional garments

\section{INTRODUCTION: OBJECTS AND CLOTHING}

Objects and, implicitly, clothes, generally speaking, are man-made, but as they are invested with meaning and make cultural categories visible (Douglas \& Isherwood 1996), it is acknowledged that they make people just as much as people make, exchange, and consume them (Gell 1998; Miller 1994). In relation to man, objects are valuable, and they trigger multi-layered values, as presented, for example, by Jean Baudrillard (1996). Firstly, there is the 'functional value', explained as the instrumental purpose of objects. Secondly, there is the 'exchange value' visible in the field of the economic meaning of an object. Moreover, thirdly, there is the 'symbolic' value assigned by the subject, which creates and/or uses objects. Lastly, there is the 'sign value' revealed only in relation to other objects. But, as artefacts embody and exhibit "personal and collective identities, aesthetic and instrumental purposes, mundane and spiritual aspirations" (Glassie 1999: 42), one must consider the different contexts in which objects are used and are given meaning. Henry Glassie, for example, emphasises three main 'master' contexts that contribute to the understanding of an artefact's 'life'. These contexts are a serviceable instrument for the 
present study: firstly, the context of creation, where individual aspirations and knowledge, which are entangled with the collective ones, are handed down by means of memory and tradition; secondly, the context of communication, which collects all the important messages or codes that are transmitted by an object within the community of its creator; and thirdly, the context of consumption, when the meanings foreseen by the creator of an object are 'eclipsed' by the ones given by the person who is using, preserving, or assimilating the object (ibid.: 48-67).

When active, objects are studied, as such, in a variety of contexts. However, concentrating more on the symbolic value of things, as the present article does, the work of Daniel Miller is considered important, since the anthropologist asserts that the meaning of clothes can only be given by the people who produce and wear them (Miller 2005: 10). The gist of this argument reveals that clothes do not merely communicate aspects of cultural and social belonging, but that they are active agents in creating a person's identity, in relation to one's gender and broader sociality. Thus, like any other artefact, clothes "embody goals, make skills manifest, and shape the identity of their users" (Csikszentmihályi \& Rochberg-Halton 1981: 1).

Following these theoretical considerations, the present article investigates the situation of traditional garments in three communities in the region of Maramureş: Dragomireşti, Ieud, and Săliştea de Sus. Our diachronic approach is looking into how this type of clothing has evolved over time and what its morphology has been in different periods of time. In doing so, we shall refer to the traditional clothing mentioned in the 20th-century ethnographic studies (Papahagi 1981; Bobu Florescu 1969; Petrescu \& Stoica 1981). Relying on an empirical approach, this study investigates, nevertheless, the different meaningful contexts of contemporary traditional clothing. We shall thus analyse the message attached to garments by the people who create and use them. Also, useful for this approach is the gist of tradition, which is perceived as a process that includes continuity and discontinuity (Handler \& Linnekin 1984: 273) as well as innovation. In this light, tradition involves the transmission of local values and the preservation of culture. But, at the same time, tradition is selective, as it reinterprets the past according to contemporary criteria concerning values (see Iuga 2011: 21-22). For this reason, as part of what is considered tradition, local clothing still has a vivid meaning and is important for contemporary communities in Maramureş. It follows the rules of tradition by adapting old shapes and values to new social and cultural needs. 


\section{MEANINGS AND VALUES OF CLOTHING}

In both traditional and modern societies, the use of garments is one of the ways in which the public self is fashioned in order to express itself not only in front of the others, members of the same community, but also in front of strangers. In order to proceed with the article, it is necessary to elaborate on the meanings and values of traditional clothing, as presented in ethnological and anthropological studies. They will be useful here, as they explain the situation in Maramureş. First, one must stress that traditional clothes have a collective value: of course, their shapes and significance are transmitted and inherited over generations, along with the necessary changes that have occurred over time due to a change in taste and values. They reflect codes, shapes, and meanings that are common to a whole social group, expressing the communitarian function of traditional art (see Bănățeanu 1985: 133-135). This function states that each community has its own particularities concerning material culture (materiality, patterns, design), which are different from those characterising any other community, even if regional common features can be found (see Zderciuc 1963; Cristea \& Dăncuş 2000). As such, clothes help people differentiate from each other within different communities: "A peasant who goes to the market and meets another peasant knows where he or she comes from, just by looking at his or her garments" (Int. 10). ${ }^{1}$ Actually, what the speaker explains is that in front of the other (the stranger), a person expresses his or her belonging to a certain community by means of objects - by clothes, in this case. Also, it is important to notice that the knowledge of how to read and understand significant details is the exclusive preserve of insiders. As artefacts, such details are meaningful only to those who know the codes embedded in them.

Extremely significant for the present study, the socio-economic function of traditional art is the second important feature of clothing (see Tzigara-Samurcaş 1987: 41). It implies that the variety of artefacts and art is given by the need to be different from one's neighbour within the same community, from other people belonging to a different social class or from a different age category. Objects are used to express social hierarchy (Stoica 1976: 6). Thus, local identity is more and more defined by material culture, even dramatically, as Gail Kligman (1998: 46) stated when conducting research in the Maramureş region in the 1980s. Thus, artefacts increase the inner competition between individuals. Similarly, Daniela Moisa's study (2008) concentrates upon the manner in which traditional clothing contributes as a visible sign to defining one's own social self. The foregoing researcher presents the situation in the neighbouring region, Oaş, which is also situated in northern Romania. She meticulously analyses the ritual clothing used during weddings, describing it, but also pre- 
senting its social meanings in a community that has radically changed in the past 25 years, as a result of the process of migration abroad. When speaking about garments during the research, my interlocutors emphasised the same socio-economic function: "Nobody agrees that both the rich and the poor wear the same clothes; there must always be something that is different, something that is grabbing attention, and people will see it immediately" (Int. 11).

The third and last aspect that is interesting for the present study is the meaning given to garments within the mainstream of the heritage-making process in contemporary cultural contexts, in which people are aware of the rapid change and partial loss of tradition. In Maramureş, there is an important movement towards the conservation of local heritage, which also includes traditional clothing preserved and displayed, for example, in regional or local museums. Since 2004, two local museums have been opened in two communities where this research was conducted (Ieud and Dragomireşti). In each of the two exhibitions, garments play an important part due to the way they are displayed and presented. These are quite recent actions. However, when analysing this tendency, we need to recall the communist legacy related to heritage conservation. When talking about the establishment of the open-air museum in Sighetul Marmaţiei (also Maramureş Department), Corina Iosif (2009) explains that during that time, a political meaning was attached to the work in the field of heritage conservation. The local festivals initiated and organised in the communist period were also crucial in changing traditional garments all over Romania. In the context of folklore performance, traditional costumes started to be standardised, as the members of professional dance groups had to be dressed in the same manner. This change in regional costume also influenced local fashion with respect to the traditional costumes from Maramureş, where people started to create clothing similar to that seen during festivals, for their own use and mainly for children. Another change provoked by industrialisation, perceived as yet another driver of change, adds to the former. Clothing was influenced and changed especially during the 1960s (Moisa 2008: 112). It was much easier to buy off-the-peg clothes, at least working clothes, which formerly used to be homemade. This change, which occurred all over the country, led to the abandonment of traditional clothing. Nevertheless, parts of the old costumes remained and were still in use in Maramureş, being combined with industrial blouses or trousers. Women wearing fancy blouses, traditional dresses, and headscarves are a telling example. In many cases, however, garments used during feasts and celebrations were and still are traditional. 


\section{CHANGING COMMUNITIES}

The study is based on an empirical approach, a field research conducted in northern Romania unequally, but in constant periods of time, between the years 2000-2013. More specifically, it was carried out in three communities located in the mountainous region of Maramureş: Dragomireşti, Ieud, and Săliştea de Sus. The three communities are situated in Iza Valley, which is considered a subregion of Maramureş (seen as a unitary region, insofar as cultural typologies are concerned), with material and spiritual culture peculiarities (Zderciuc 1963: 7). It evinces a regional sense of belonging whose importance is expressed by its inhabitants as part of their local identity. The research focused on the material culture of the region, mainly textiles prepared as part of women's dowry, as well as clothes used for festive occasions, which form the basis of the present article. Maramureş is one of the most conservative Romanian regions that are marked even by some archaism. Here one can still find wooden constructions (old and new churches and houses). Rituals are still important and people still wear traditional clothing. But, like in any region, intense transformations are the result of the area's strong social and cultural dynamic. Here tradition is continued, though vividly changed and adapted to the new requirements of the communities. The dynamic of tradition is best illustrated by local garments embedded in a cultural, social, and personal meaning to be detailed later in this study.

This region is not only conservative but also marked by changes which, among other cultural and social aspects, have also affected local clothing. But this statement makes the historical approach necessary for a better understanding of the cultural and social values of the region. Maramureş has an important historical tradition. Documents speaking about important families and events in the region date from the 14th century. The social structure of the region at the time, and until the mid-20th century (until the end of the Second World War), was based on a social structure that values the noble peasants (called nemeşi) from the region. This structure still contributes to ordaining social relations in contemporary villages (Kligman 1998: 30). Thus, village life cannot be understood without its reference. This aspect is even more worth stressing, as each of the three communities can be considered a "memory collectivity", as defined by Sanda Golopenţia-Eretescu (2001: 36-37): all the members of the social group know each other, are familiar with their lineage and nicknames, communicate with each other and establish ritual contact with each other. In such a community, it is important that each of its members stresses and confirms in some respects their social status and belonging to one class or another. This 
is also done by means of objects, which are sometimes ostentatiously used for ritual display (Kligman 1998: 45).

Over time, the region has been affected by social and political changes that have also caused a cultural change. The most important one occurred after the Second World War, when the communist regime came to power in Romania. On this occasion, all the three villages were subjected to collectivisation and punishing acts against the peasants and intellectuals that stood against the political regime at the time. This meant that land ownership changed and peasants were deprived of their property. Later on, it was common for the people living in all three communities to search for work elsewhere (in other parts of the country). After the fall of communism (which occurred in 1989), search for work abroad became more intense, especially after the year 2000, when Romanian citizens no longer needed visas in order to travel to Europe. Due to the opportunity to travel to other regions or countries, people have broadened their horizon, although wherever they go, they symbolically re-create their native community because there is a strong attachment to their native village:

People who go elsewhere re-establish Săliştea de Sus [native village] where they are, in whatever city they are; but there are also those who come back and build their home on the ground that once belonged to their ancestors. (Int. 11)

If people from one village go and settle elsewhere, either in Romania or abroad, they also re-create their community symbolically by means of material culture. Garments are an important aspect of it (Iuga 2015), as shown by the research made in a Spanish community where people from Maramureş migrated to find work.

What kind of change took place in native communities? Although political changes imply social change, people are still attached to their traditions, which are adapted, of course, to contemporary values. Woollen textiles are still used to decorate the interior of big houses, especially the festivity room called "dressed in a peasant manner", which displays all the textiles prepared for women's dowry (Iuga 2011). Nowadays people get modern clothes very easily. However, on important occasions or on feasts, they use traditional costumes with new pieces imported from elsewhere and transformed into local pieces that acquire a new meaning. Festive garments are presented in detail in the following sections in which I shall explain why and how people find them important, given that they are suggestive of local identity. 


\section{OLD TRADITIONAL CLOTHING}

Ethnographic studies on the Maramureş region provide a thorough description of the traditional festive costume, its shapes, colours, patterns, and sometimes ritual use (Cristea \& Dăncuş 2000; Cuisenier 1994; Bobu Florescu 1969). These studies claim that in terms of general typology, these clothes are basically unitary in shape and cut, with sub-regional differences concerning their colours and patterns, sometimes mentioned in the studies (Zderciuc 1963; Cristea \& Dăncuş 2000). Broadly speaking, the costume of the Maramureş region is made up of general components. Men's clothes are very simple: white hemp shirt and trousers during the summer (Fig. 1), with a waistcoat made of sheep skin or felt, decorated with various techniques and patterns that differ from one village to another. Thus, it has an important communitarian function. During the winter, men's trousers are made of felt. The shirts they wear are decorated around the V-shaped neck and sometimes have a collar. The sleeve ends are decorated. The sleeves are wide (a peculiarity which differs from one village to another, as in some villages the sleeves are not voluminous). Thus, men usually wear colourful

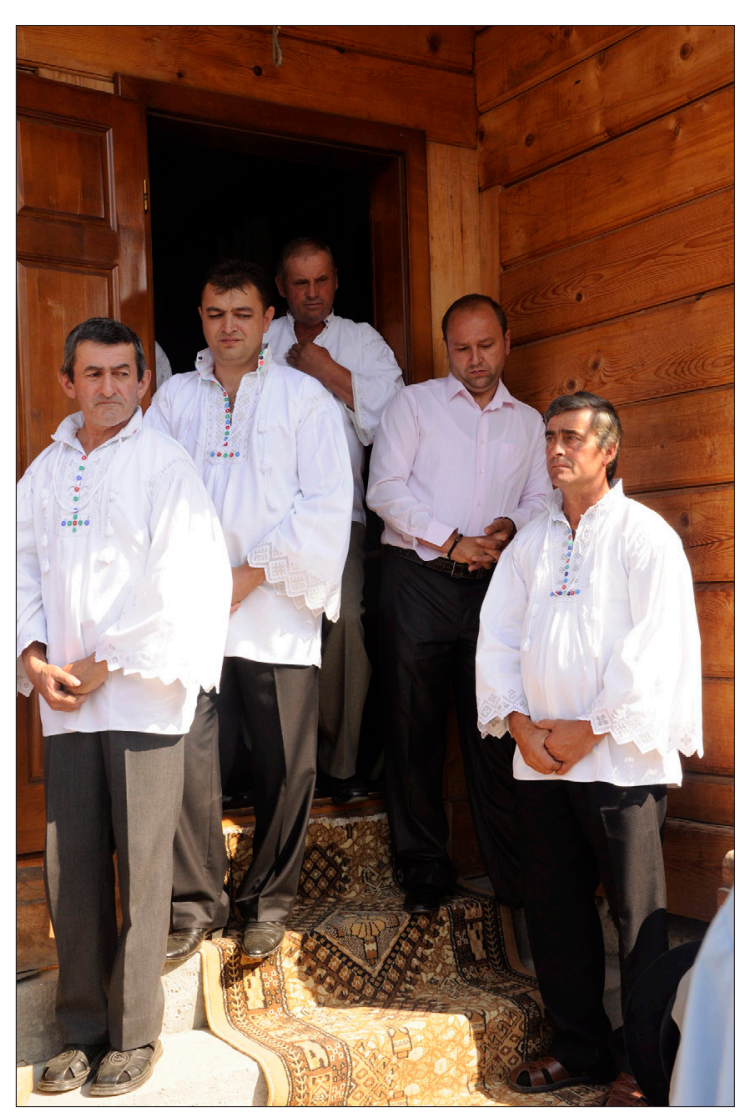

woollen cuffs during the winter. Men's hats are usually made of felt, bought at the local market. During the summer, they wear a straw hat of a peculiar shape, which is popular in Cosău Valley (another sub-region) where one can still find artisans who produce them (Fig. 2).

Figure 1. Men's clothing in Iza Valley. Celebration of the patron saint in Dragomireşti in 2010. Photograph by Anamaria Iuga. 


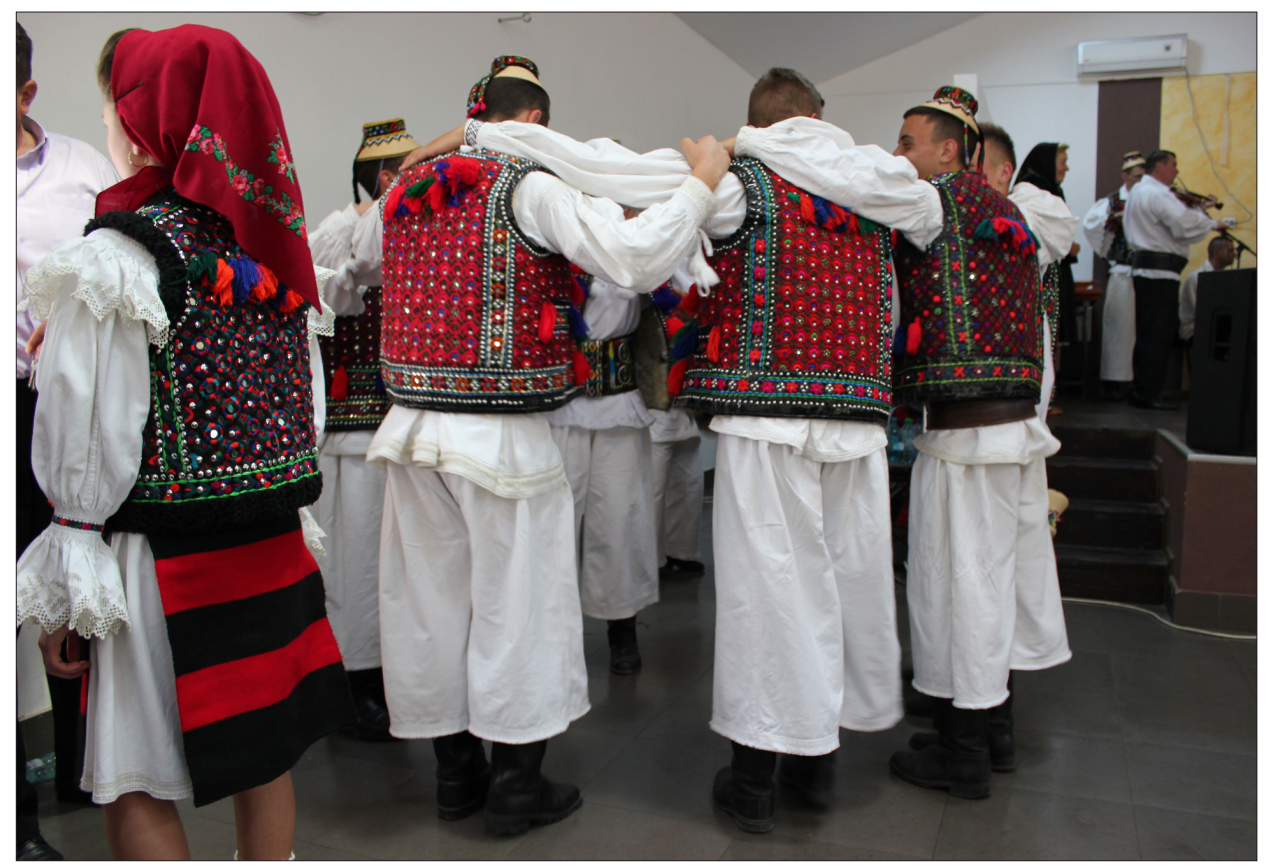

Figure 2. Men's clothing in Cosău Valley. Local festival in Şieu in 2015. Photograph by Anamaria Iuga.

Women's clothes include a long white hemp shirt, or a short shirt with a square neckline, and a white underskirt, with colourful patterns that are usually geometrical or floral; the shirt is voluminous and decorated around the wrists and at shoulders. In the front and at the back, the underskirt has two aprons that are locally called zadie. They are made of wool, with wide black and red, orange, yellow, green, or blue stripes (Fig. 3). These colours differ from one village to another, and, within a specific village, from one age category to another. Actually, a headscarf is not necessarily worn with festive clothes - it is worn on a daily basis. This textile item is usually inherited or bought at the local market. A waistcoat is always worn during the cold season. It is made of sheep skin, intensely decorated, and fulfils the same communitarian function as men's waistcoats. In the wintertime, both men and women wear coats made of felt, but their colours vary according to the specificity of different communities or sub-regions (for example, they are usually dark-coloured in Iza Valley).

Of course, these costumes are different as regards the sense of belonging to one village or another. The three villages where the research was carried out reveal a difference in details, colours, patterns, and sometimes even in 
Figure 3. Women's clothing in Cosău Valley. Local festival in Şieu in 2015. Photograph by Anamaria Iuga.

shape. Men's clothing is different, and this is visible in the waistcoat they wear. In all the three villages, brown leather is the background of the waistcoat, but the

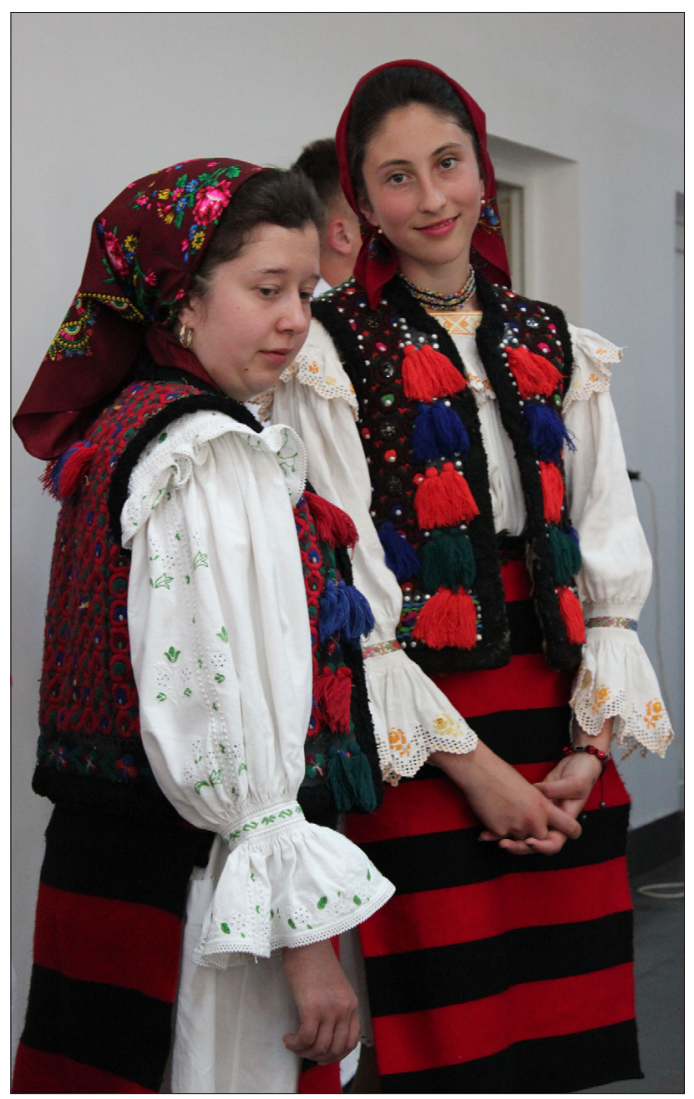
patterns are distinct. In Săliştea de Sus, men still wear the old type of waistcoat, both with floral ornaments and bumbi (buttons), a decorative detail that only has an adorning function; in Dragomireşti, coloured tassels are attached to the waistcoat; in Ieud, it is adorned with simple floral ornaments sewed on leather. Nowadays men wear traditional clothing only on very special and festive occasions as they have abandoned traditional garments more easily (see also Moisa 2008). Important religious feasts, such as Easter, the celebration of the patron saint of the village, or weddings are just a few occasions when traditional clothing is worn. But on these occasions, men's clothing is half traditional, half modern, as the white hemp trousers are usually replaced by black trousers bought at common shops.

Women, on the contrary, seem to be keener on wearing traditional clothing. On various, though highly festive occasions, they still wear the garments presented above. They display local characteristics, for they are considered to be festive clothing. In each village, for example, leather waistcoats are different and similar to men's ones in shape, patterns, and colours. In Săliştea de Sus, though, fashion has somehow changed more rapidly, so the waistcoat is 


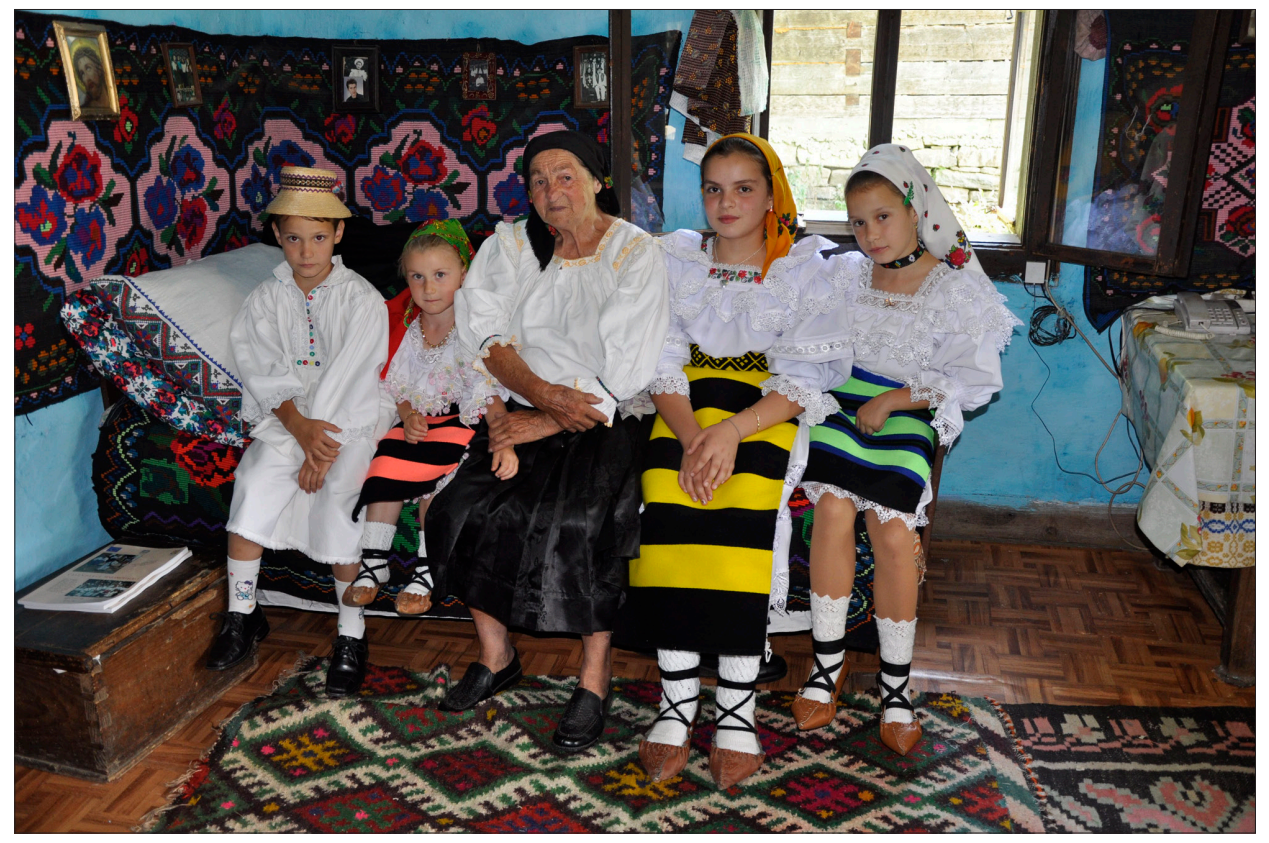

Figure 4. Contemporary traditional clothing. Dragomireşti 2010. Photograph by Anamaria Iuga.

also changing. As people recall, in the 1960s-1970s it was fashionable to wear a waistcoat that came from the neighbouring city of Vişeu. It is mainly made of felt and the decoration is sewed in green wool thread. Even its name-vişeonesctells the place of its origin (meaning "from Vişeu"). As fashion is constantly changing today, the waistcoat has been replaced with a different one, which is more specific to the region of Bucovina (north-eastern Romania), where leather is not decorated at all. It is only bordered with fur around the shoulders and the neck hole of the waistcoat. White shirts are also changing. Since the late 1990 s, it has been common to have a white shirt made of synthetic material, not of hemp. Although it is more easily sewed, the interlocutors always speak about the good quality of hemp shirts (Fig. 4). The reason why this shirt is so popular has a social background, as everybody has to be careful to local fashion, especially young girls, as "wearing an old shirt would be considered a disgrace" (Int. 11). Last year, though, more and more women returned to hemp shirts. They are now highly appreciated, as seen at a wedding in the village of Ieud in 2015. But the woollen apron worn by women is the most visible and important sign, which shows a person's belonging to one or another community. Aprons have a particular colour and design in each of the three villages under study: 


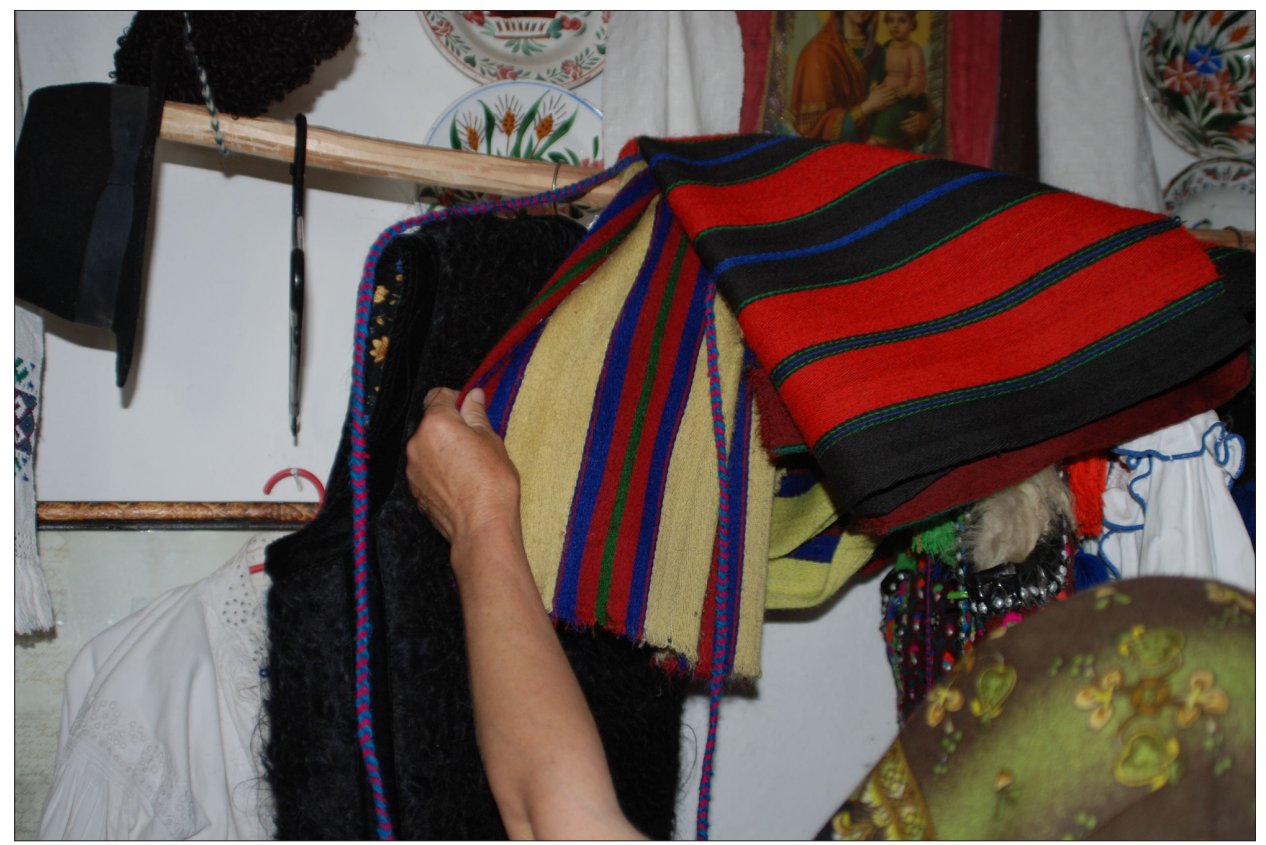

Figure 5. Women's woollen aprons. Ieud 2010. Photograph by Anamaria Iuga.

Every village is different and we know it [when looking at aprons]. In our village, the stripes are not that wide, they are tighter. In Săliştea, both the black and the red stripes are wider [---] there is also a difference in Ieud, as you have seen. There is a different shade of yellow, which differs from the one we use; it is closer to orange, somehow. Ours is like a pumpkin's flower. We know where a woman comes from because we are familiar with different types of aprons. (Int. 9)

Difference can be expressed by clothes within a community as well. For example, colours differ according to the age and marital status of the woman who wears them (as Int. 6 also explains). A distinction between the aprons worn by girls and married women used to be made in all the three villages: "I cannot wear the same clothes as my daughter. Because she is younger, I give her yellow aprons. Mine are red" (Int. 9). Girls wear aprons with alternating black and yellow stripes. Of course, each village has a different shade of yellow. Orangeyellow, called pumpkin yellow, is typical of Săliştea de Sus and Dragomireşti (Int. 2). It is sometimes combined with thin stripes of blue (as it happens in Dragomireşti). The difference between the two communities resides in the stripe width. In Ieud, the yellow colour is not so orange-like and is combined with thin 
blue and red stripes towards the bottom of the apron (Int. 6). Married women wear aprons with black and red stripes whereas young married women in Ieud still wear mainly yellow or orange-yellow aprons. Unlike the aprons worn by girls, the latter lack the additional stripes in other colours, red or blue (Fig. 5). They are simpler. In the past 40 years or so, aprons have also been subject to change. The materials used to weave them have been modified. Wool has been replaced by synthetic fibres. Colours have also changed. It is now common to wear an apron with red and black stripes, such as those worn by traditional music singers on television. The variety of colours and the social difference conveyed by clothes has been put aside.

Although this type of traditional clothing is considered to be old, people still wear it on important occasions. According to them, the reason is that this costume will never go out of use, as it seems that "nothing has changed. People still wear the same clothes they wore ages ago" (Int. 11).

\section{NEW TRADITIONAL CLOTHING}

Clothing changes according to fashion and even traditional clothing follows the logic of fashion that normally remains within the limits imposed by local traditions. But a radical change, which exerted a major influence on the local garments in Maramureş, occurred at the beginning of the 20th century. Buying clothes at markets and shops has become easier. This has led to the disappearance of home-spun clothes. In this regard, men have been less conservative than women: they readily prefer urban to traditional clothing. Women's clothes have also changed, but they still follow traditional rules when it comes to their functions. At the turn of the 20th century, richer families (as "wealthier people are the first to provoke change" - Int. 11) started to purchase industrial textile materials at the market or, probably, at shops in larger cities, and to use them to make skirts similar to the ones they probably saw in the city. These voluminous skirts are locally called sumnă rotată (round skirt), as Tache Papahagi noted in his study first published in 1925 (Papahagi 1981: 99), or simply sugna or sumna. The word derives from the Hungarian word szoknya (skirt). This richly coloured piece of garment is usually made of cashmere, with floral patterns. It is a textile item that is commonly used in the traditional clothing of Central Europe, mainly the Northern Carpathian Mountains: not only in Maramureş and Ukraine but also in Hungary, Slovakia, and Poland. Concerned with the origins of this material, the research was oriented towards the Polish example, where this type of textile is called tybet, the Polish name for the Tibet region. 
Thus, the name signals the original place of this type of wool, a material used for weaving this piece of special cloth. ${ }^{2}$ In naming this cloth, the regional denomination remained the same, although textiles began to be made of other materials, such as cashmere, or even synthetic fibres.

This textile does not have a special name in the Maramureş region, but it is still used to design special skirts that are now labelled as traditional clothing, along with the older type, which is now regarded as festive clothing. As mentioned before, it appears in research carried out in the early 20 th century (Papahagi 1925), and over time, especially after the Second World War, when market goods were easier to purchase, this skirt has gained in importance in such a way that the generation of those who are now in their fifties already consider it part of the local costume: "Since I was a child, I wore this dress and peasant sandals (opinci); this is what was worn by everybody in my early days" (Int. 1). Partially replacing the long white hemp shirt, this skirt is now combined with industrial T-shirts or blouses. However, it is usually worn together with a shorter shirt, especially on festive occasions. The underskirts are no longer worn with two aprons. More importantly, this skirt became part of what today is considered to be traditional clothing in Maramureş. It has even taken over the identification functions of the aprons, marking the community sense of belonging and age category. Also, as mentioned by ethnographers, it has "particular identification tokens for each village" (Cristea \& Dăncuş 2000: 76), special markings found in colours and patterns. When wearing this new type of local clothing, women usually match the skirt with the headscarf, both being crucial for expressing their marital and social status within the community. Thus, unmarried young women wear vividly coloured skirts and headscarves with floral patterns on a red, blue, green, or even white background (Fig. 6). Young married women also wear this kind of skirts and headscarves in their first years of marriage. After 35 years of age, women start to wear colourful skirts and headscarves with paler nuances (Fig. 7). After turning 50, they wear only skirts in one colour. These are usually brown, dark blue, or dark green, with a much simpler headscarf lacking so many floral patterns on the textile material. Sometimes it has "only a small flower on the back" (Int. 4). In their sixties, women are already considered to be old. Their clothes stand solid proof of this assertion. They usually wear clothes in black colours: a black skirt and a black headscarf patterned with little flowers. Even older women wear one single striped apron over the skirt, either behind or in front of the black skirt. This apron is usually part of the first type of local clothing (white hemp shirt, white long underskirt, and two woollen aprons with black and red stripes, one worn at the front, and one at the back side of the underskirt). 


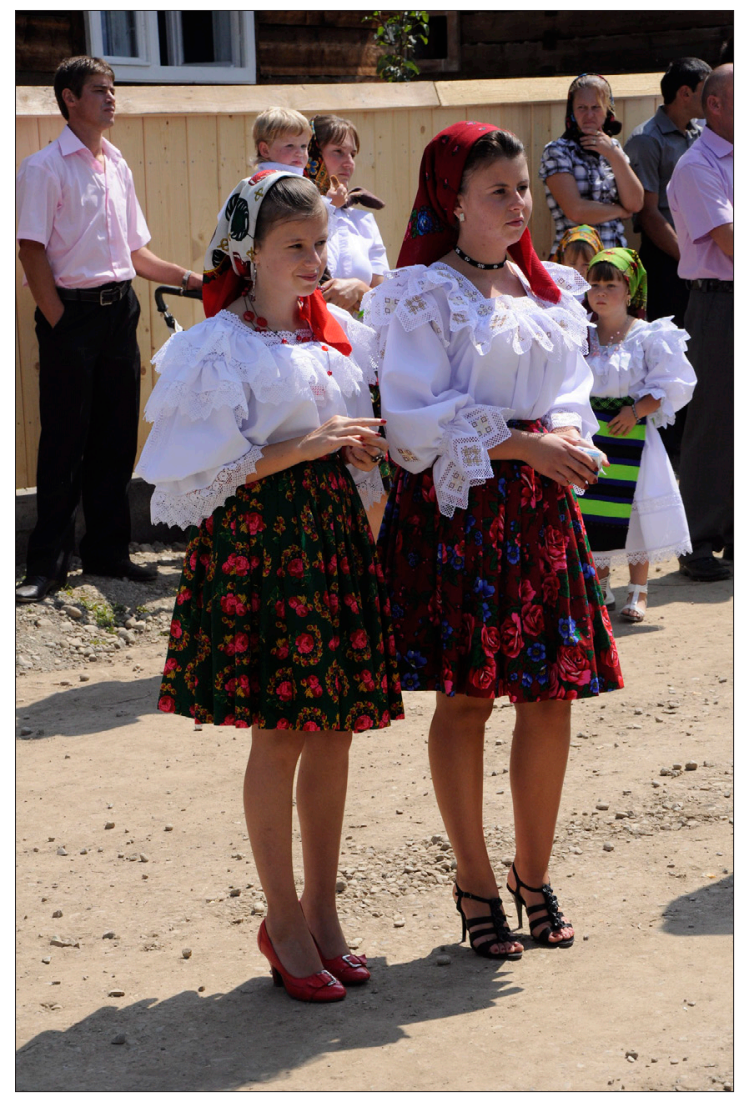

Figure 6. Contemporary traditional clothing. Unmarried young women. Dragomireşti 2010. Photograph by Anamaria Iuga.

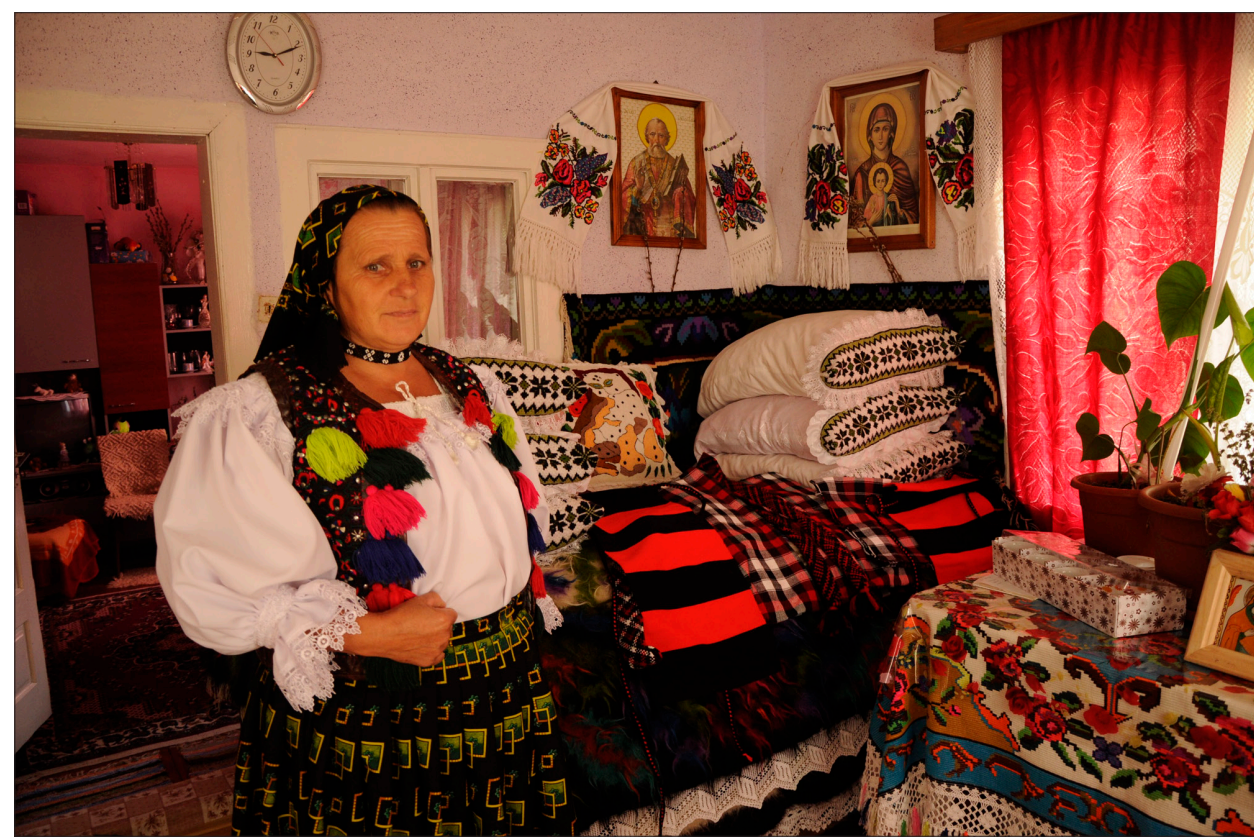

Figure 7. Contemporary traditional clothing. Married woman. Dragomireşti 2011. Photograph by Anamaria Iuga. 
Regarding all these characteristics, this type of costume is now considered to be the traditional one in these three villages. Even on highly festive occasions, women can choose to wear this type of clothing, not the old one made up of two aprons and white shirts, which people describe as the very festive one. Actually, it is a matter of people's choice. Nevertheless, in the past years, the costume with a colourful skirt has been increasingly used at local festivals where performers are usually dressed in old traditional garments.

\section{OLD AND NEW TEXTILES}

As was already mentioned in the descriptions of the two types of traditional clothing, I was able to notice that the locals generally tend to maintain that nothing has changed in the shape of clothes. Yet, "something new comes up all the time, whereas something typical of these garments fades away" (Int. 11). This change is caused by the constant competition between people within a certain community, who "do not want to lag behind the rest of the village" (Int. 5). As was seen above, all villages are marked by an important dynamic of the traditional costume. This dynamic can be noticed particularly in women's clothing, as men do not seem to be so interested in local fashion. The general tendency is to easily adapt what is new, as the old is no longer considered so meaningful or valuable. Instead, new pieces of clothing are highly appreciated for their money value: "People consider that something new is beautiful, [it should be both] new and expensive. It has to be very expensive. Actually, this is the main criterion" (Int. 11). Change can also occur as an impact from another community or cultural space. Today both men and women travel and see other regions both in Romania and abroad. They have the opportunity to see what garments look like elsewhere. Sometimes they come home and create innovative garments "seen, liked, and taken; one takes something from elsewhere and adapts it to his or her clothing. You adapt it in such a manner that no one can say that you copied someone from another village. You adapt it to such an extent that they will say that it is your own, that it is your own doing and conception" (Int. 11). Fast-paced fashion is strictly linked to the need of expressing one's identity (see also Moisa 2008: 122-124).

This tendency has determined both types of traditional clothing to be subject to change. For the old two-apron costume, change occurs in the new materials used for the creation of shirts (currently synthetic materials with different patterns and decorations that are made by machines, not by hand) or aprons (also synthetic materials with a slight change in colours). More importantly, one must observe that the coloured stripes on the aprons have been standard- 
ised. Old shirts or old types of clothing are not so much appreciated because they are old-fashioned, although a new tendency to value them has emerged this year. Fashion is changing. As for the other type dominated by a colourful dress, one can notice a tendency to introduce innovations and to treasure what is old. The introduction of a new coordinate, a new context of use - migration abroad - is important. During a research project carried out in 2013 in a community situated in the region of Almeria (Spain), where migrants from Săliştea de Sus work and live, I noticed that women bought textile materials at the local market in Spain in order to make voluminous skirts or to send the materials back home so that the other members of the family could create new, unique skirts. This action responds to the pressing social and aesthetic requirement of differentiating oneself, and reveals the important dynamic of this garment in the communities from Maramureş (Iuga 2015).

The new and the uncommon are valued to a greater extent, but, paradoxically, the old is also valued when it comes to colourful skirts and headscarves because these pieces of clothes are becoming uncommon. They are considered to be more valuable because they are older, because the fabric is believed to be of better quality: "The old ones need no ironing; they are more beautiful and last longer" (Int. 1). Even the patterns are seen as colourful and more beautiful than the fabrics that can now be bought at local markets. Their rarity is also a reason to value them more and determine the rise in their price: "Only richer women have old headscarves because not everybody can afford to pay millions of lei for one scarf" (Int. 1). Thus, wearing old skirts and scarves is important for showing one's own social and economic status in the community: "When you go to a wedding or to church, or just walk in the village on Sundays, you can only wear very old [scarves and skirts], so everybody would be jealous" (Int. 11).

If a normal skirt made of a new fabric costs around 25 euro, the price of an old one can amount to 150 euro, as seen at the local market (Dragomireşti, August 2015). Headscarves are sold at an even higher price because they are highly appreciated. In 2001, V.I. (Int. 11) recalls, her neighbour sold two scarves for 500 euro; in the summer of 2015, in the market in Dragomireşti, a woman remembers having sold an old scarf for 800 euro to another woman who used it during a wedding ritual as a gift for her future daughter-in-law. It is important to observe that these expensive clothes are mainly used by unmarried young women in order to gain men's interest and people's admiration. For example, I.V. (Int. 8) recalls that, in order to gain the community's attention and appreciation, she gathered exquisite clothes for her daughter before the latter got married: 


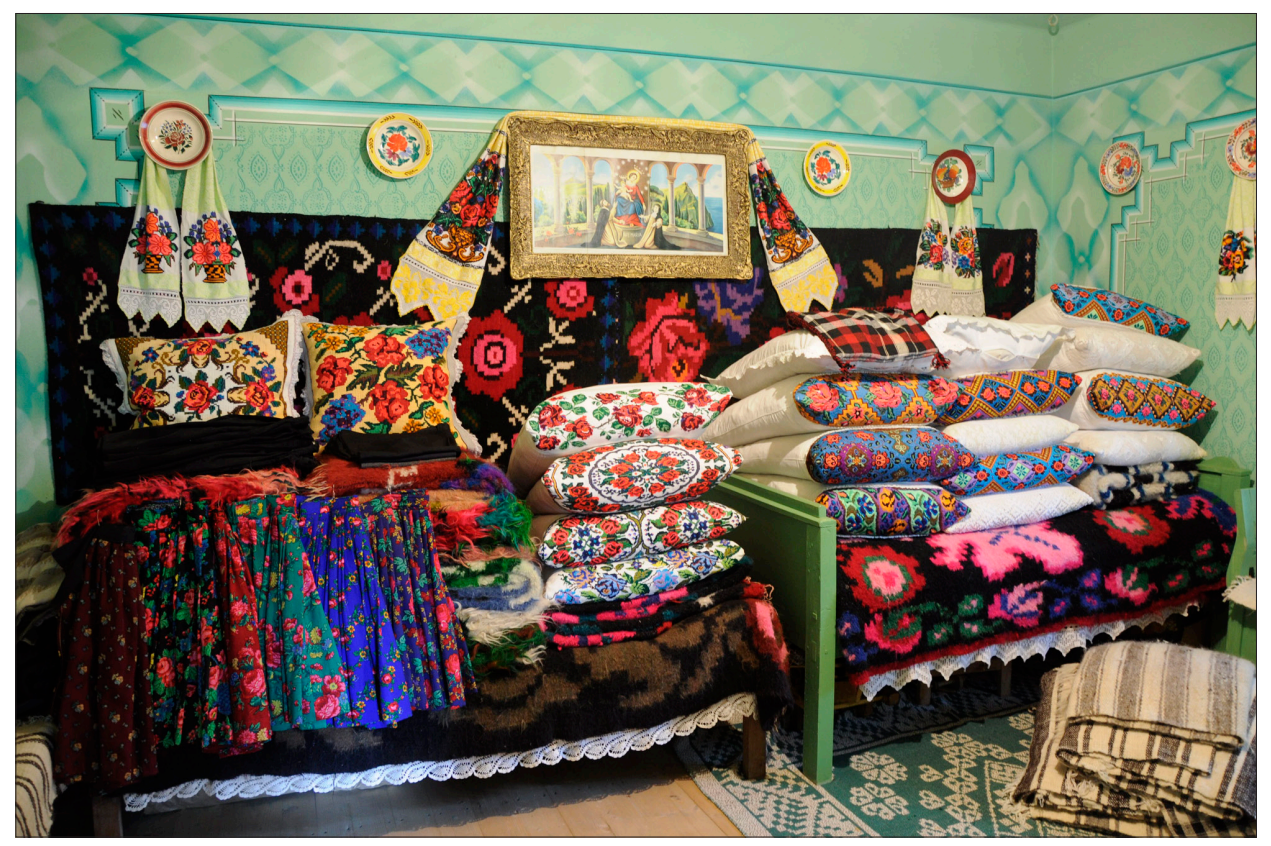

Figure 8. Skirts hanging on the bed in the festive room. Săliştea de Sus 2011. Photograph by Anamaria Iuga.

I designed so many peasant costumes with old scarves for her, each of them summing up to 10 million, 15 million [lei - approx. 400 euro]. [---] These are soft and do not crumple. Insofar as holy days are concerned, people wonder what my girl was adorned with at Easter. With this and that, I answer. [---] 200 euro for each skirt. [---] The most expensive [headscarf] was 1000 euro. I found it in Certeze, in the Satu Mare region. [---] Value counts. We have old scarves, just as someone else has luxurious cars. (Int. 8)

Both new and old colourful skirts that are more valued are so important that people need to show them off even when they are not worn. They are highly taken care of and are kept in important places in the house (Fig. 8). They are hung on the wall or kept in visible places in the festive space of the peasant house or in the 'good room', a space used only on festive occasions, such as religious feasts or life cycle rituals (Iuga 2011). 


\section{NEW CONTEXTS OF USE}

Traditional clothing plays an important role not only in stressing one's own identity within the native community but also in relation to other communities in the same region. In the last part of this article, I would like to explain what happens with this garment when linked to migration abroad seen as a new cultural context. It is one of the social phenomena that were common to the studied region even during the Austro-Hungarian Empire, of which Maramureş was also a part. The people of this village used to go to the bigger cities of the empire to sell their products: wood, fruit, etc. (Papahagi 1981). Establishing borders between countries after the First World War reduced people's mobility. But during the communist period, especially after the collectivisation process, when land ownership changed in favour of the state, people needed to search for work outside the region. Transylvania and the south-western part of Romania were the main regions where they went for seasonal work. This "circular migration" (Sandu 2000) was common to men and women alike. After the fall of communism, this type of migration continued, but people started to travel abroad, especially after 2000. This has increased the importance of the function of traditional clothing, that of expressing the sense of belonging to a community and a region. Altogether, new uses, such as the acknowledgement of the heritage value of these garments, can be foreseen. This is the case of the Romanian community of migrants in Spain. Originating in Maramureş, they take pieces of traditional clothing or entire costumes in order to be worn on festive occasions:

Here I go to church [the Romanian Orthodox Church in Spain] and I dress in my own traditional suit. I have my shirt, my skirt; I have them all. [---] I never part from my shirt! When I have my shirt on and put in an appearance at church, everyone can notice that I have arrived [in the church]. (Int. 3)

Also, the children who live with their parents in Spain have traditional garments from the Maramureş region. They wear them, although, in some cases, they have never been to Romania, and, as a consequence, to Maramureş, and to the native village of their parents. It is important, thus, to notice that clothing is one of the most important items of material culture used by parents to make the children become aware that it is the Maramureş community, not the Spanish one, which stands for their identity mark:

Yes, I have peasant clothes for my children. Here they have this custom, children go to school dressed as Santa Clauses, shepherdesses or shepherds, as they say. So shepherds have some clothes like those of our 
peasants. The only difference is that instead of being multicoloured, their skirts are red and have a green apron. [---] I bought traditional sandals, a shirt, and a skirt from Maramureş for my daughter, and I even took her to the kindergarten dressed in these clothes for their Christmas party. [---] Everybody wondered how come this girl had such beautiful and special shepherdess clothing. I do not care, they are Spanish here, I do not know, I do not care that much. But she must be dressed like in Maramureş. (Int. 7)

Thus, using traditional clothes in the host country is a way for Romanian migrants to be connected to their native community by means of the tangible heritage they use. At the same time, it is also an important way of informing the Spaniards about their specific culture (Iuga 2015).

The heritage-making process is yet another context that produces a change in the way that traditional clothing is perceived in Maramureş. In the region, traditional clothing is also considered important within this logic, when in use during local, regional, or national festivals. These festivals value both old traditional dances and old traditional costumes. Participants usually have the same type of clothing, a somehow standardised one, in the same colours, shapes, and patterns (Fig. 9). However, an independent singer or a leader of a group is trying to differentiate him- or herself from the others, by using old traditional pieces of garments. These garments usually belong to their family and emphasise the difference. It is also important to mention that old garments are given more points by the jury at certain festivals and competitions involving traditions, thus being much more appreciated.

Local museums also contribute to the heritage-making process, as the traditional garments exposed there become a tourist attraction. In some places, people are allowed to try them on in order to see what it feels like and to experiment local culture. In this context of use, garments contribute to the museum's discourse meant to explain the cultural particularities of the region. When people try them on just for fun, they experience local culture, even if temporarily. It is thus important to notice that this has always been a common practice among the inhabitants of Maramureş. They invite strangers, such as tourists, to try on the local garments, to go to church or the village dressed like this, or to simply put them on when taking a picture of themselves. Once again, this practice shows that the natives are proud of their traditional clothing and that the latter has an important representative function. Also, it shows that the traditional clothing becomes a means to boast of their specific local culture and values, and, consequently, their cultural heritage to the others (strangers). 


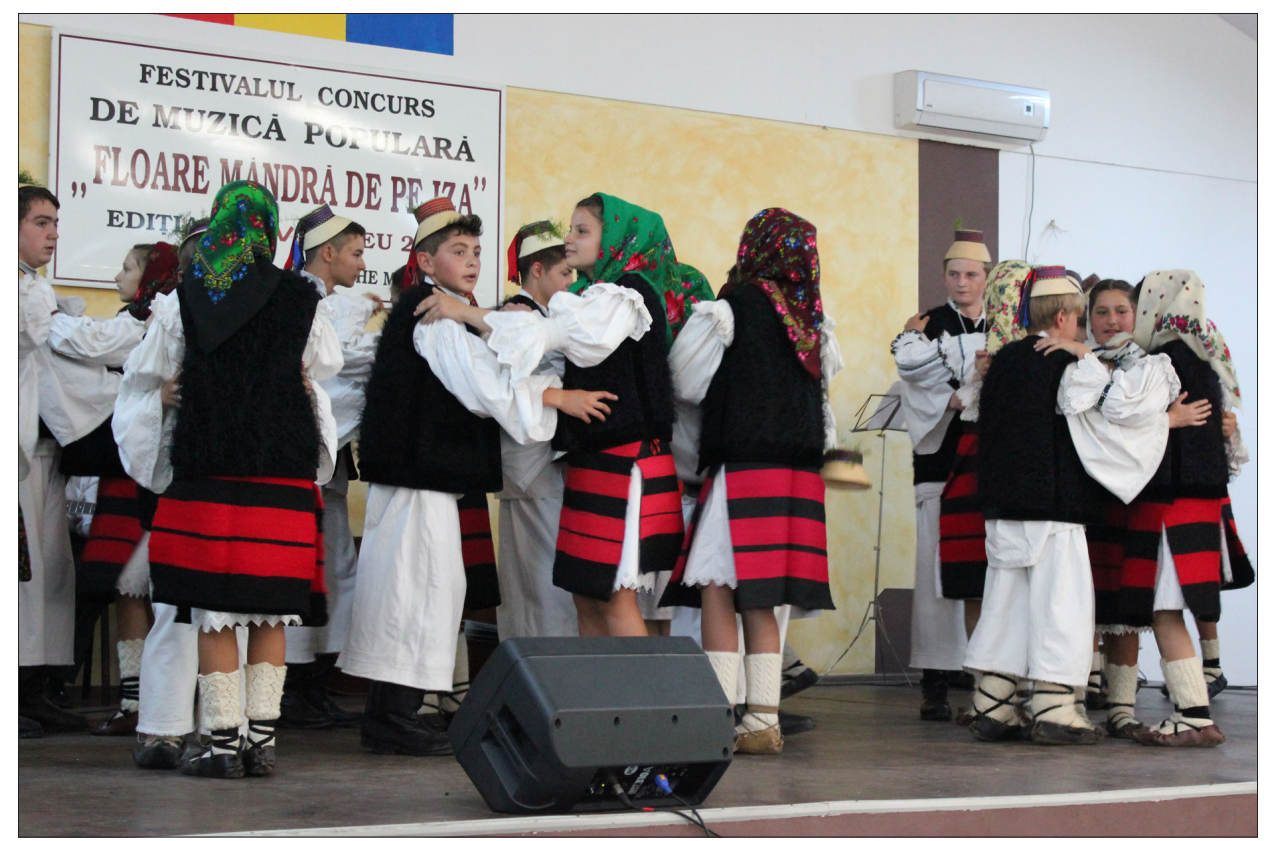

Figure 9. Local festival in Şieu in 2015. Photograph by Anamaria Iuga.

\section{CONCLUSIONS}

When investigating traditional clothing in the Maramureş region, one could notice an interesting dialogue between old and new, continuity and change, and how they oppose each other or intertwine. Attention has been paid to the contemporary fashion of the local costume with its two aspects: an older type continuing the local tradition, and a newer one, which has initiated a new trend that is now regarded as tradition. Stressing the meanings they carry within, these artefacts have been presented in their contexts of use. I have thus emphasised how they contribute to highlighting local identity and one's own public self within the same community. The common denominator of all these aspects is that local garments express the pride of belonging to a specific region and community with particular cultural characteristics. It is thus salient that the use of traditional clothing ensures a strong sense of belonging and cultural identity by illustrating local heritage in both local museums and festivals. Still in use for the life of the community and related to other communities/regions/ nations, traditional clothing is, therefore, an important, meaningful, and dynamic cultural aspect of the local communities in the region of Maramureş. 


\section{NOTES}

1 This research was conducted in Romanian language. The English translation of the interlocutors' (marked as "Int.", with a list at the end of the article) words was made by the author of this study.

2 This information is available online at www.polartcenter.com.

\section{REFERENCES}

Bănățeanu, Tancred 1985. Prolegomene la o teorie a esteticii artei populare. [Introduction to the Theory of the Aesthetics of Popular Art.] Bucharest: Minerva.

Baudrillard, Jean 1996. Sistemul obiectelor. [The System of Objects.] Cluj-Napoca: Echinox. Bobu Florescu, Florea 1969. Portul. [Garments.] In: F. Bobu Florescu \& P. Petrescu (eds.) Arta Populară Românească. [Romanian Folk Art.] Bucharest: Academia Republicii Socialiste România, pp. 277-415.

Cristea, George \& Dăncuş, Mihai 2000. Maramureş, un muzeu viu în centrul Europei. [Maramureş, a Living Museum in the Centre of Europe.] Bucharest: Fundaţia Culturală Română.

Csikszentmihályi, Mihály \& Rochberg-Halton, Eugene 1981. The Meaning of Things: Domestic Symbols and the Self. Cambridge: Cambridge University Press.

Cuisenier, Jean 1994. Le feu vivant: La parenté et ses rituels dans les Carpates. Paris: Presse Universitaires de France.

Douglas, Mary \& Isherwood, Baron 1996. The World of Goods: Towards an Anthropology of Consumption. London: Routledge.

Gell, Alfred 1998. Art and Agency: An Anthropological Theory. Oxford: Clarendon Press. Glassie, Henry 1999. Material Culture. Bloomington, IN: Indiana University Press.

Golopenţia-Eretescu, Sanda 2001. Intermemoria: Studii de pragmatică şi antropologie. [Inter-Memory: Studies in Pragmatics and Anthropology.] Cluj-Napoca: Dacia.

Handler, Richard \& Linnekin, Jocelyn 1984. Tradition, Genuine or Spurious. The Journal of American Folklore, Vol. 97, No. 385, pp. 273-290. http://dx.doi. org/10.2307/540610.

Iosif, Corina 2009. Politica tradiţiei: Practici de muzeologie etnologică în perioada comunistă. [Politics of Tradition: Ethnological Museum's Display in the Communist Period.] In: A. T. Sîrbu \& A. Polgár (eds.) Genealogii ale postcomunismului. [Genealogies of Post-Communism.] Cluj-Napoca: Idea Design \& Print, pp. 283-308.

Iuga, Anamaria 2011. Valea Izei îmbrăcată ţărăneşte: Camera bună - dinamismul tradiţiei. [Iza Valley Dressed in a Peasant Manner: The Good Room - Dynamics of Tradition.] Târgu Lăpuş: Galaxia Gutenberg. Available at http://www.academia. edu/1872740/VALEA_IZEI_IMBRACATA_TARANESTE, last accessed on October 13, 2016.

Iuga, Anamaria 2015. Rebuilding Communities through Their Heritage: Migrants from the Maramureş Region (Northern Romania). In: D. Moisa \& J. Roda (eds.) La diversité des patrimonies: Du rejet du discours à l'éloge des pratiques. Québec: Presses de l’Université du Québec, pp. 107-130. 
Kligman, Gail 1998. Nunta mortului: Ritual, poetică şi cultură populară în Transilvania. [The Wedding of the Dead: Ritual, Poetics, and Popular Culture in Transylvania.] Iaşi: Polirom.

Miller, Daniel 1994. Artefacts and the Meaning of Things. In: T. Ingold (ed.) Companion Encyclopedia of Anthropology. London \& New York: Routledge, pp. 396-419.

Miller, Daniel 2005. Introduction. In: S. Kuchler \& D. Miller (eds.) Clothing as Material Culture. Oxford: Berg, pp. 1-19.

Moisa, Daniela 2008. Du costume traditionnel à Barbie: Formes et significations du costume "traditionnel" de Certeze, Roumanie (1970-2005). Martor: Revue d'Anthropologie du Musée du Paysan Roumain, Vol. 13 (Artcraft Market), pp. 109-130. Available at http://martor.muzeultaranuluiroman.ro/wp-content/ uploads/2015/07/moisa_site1.pdf, last accessed on October 13, 2016.

Papahagi, Tache 1925. Graiul şi folklorul Maramureşului. [Maramureş Dialect and Folklore.] Bucharest: Cultura Naţională. Available at http://teofil-ivanciuc.weebly. com/take-papahagi--graiul-351i-folklorul-maramure351ului-1925.html, last accessed on November 2, 2016.

Papahagi, Tache 1981. Grai, folklor, etnografie. [Language, Folklore, Ethnography.] Bucharest: Minerva.

Petrescu, Paul \& Stoica, Georgeta (eds.) 1981. Arta Populară Românească. [Romanian Folk Art.] Bucharest: Meridiane.

Sandu, Dumitru 2000. Migraţia circulatorie ca strategie de viaşă. [Circular Migration as Life Strategy.] Sociologie Românească, No. 2, pp. 5-29. Available at http://www. arsociologie.ro/arhiva-sociologie-romaneasca/21-revista-sociologie-romaneasca/ rezumate/865-sandu-2-2000, last accessed on October 13, 2016.

Stoica, Georgeta 1976. Podoabe populare româneşti. [Romanian Folk Ornaments.] Bucharest: Meridiane.

Tzigara-Samurcaş, Alexandru 1987. Scrieri despre arta românească. [Writings on Romanian Art.] Bucharest: Meridiane. Available at https://monoskop. org/File:Tzigara_Samurca\%C5\%9F_Alexandru_Scrieri_despre_arta_ rom\%C3\%A2neasc\%C4\%83_1987.pdf, last accessed on October 13, 2016.

Zderciuc, Boris 1963. Covorul maramureşean. [The Carpet from Maramureş.] Bucharest: Meridiane.

\section{INTERLOCUTORS}

Int. 1: A.L., 2001, aged 47, Săliştea de Sus

Int. 2: D.I., 2013, aged 71, Baia Mare

Int. 3: F.I., 2013, aged 38, Spain

Int. 4: F.P., 2001, aged 38, Săliştea de Sus

Int. 5: I.B., 2001, aged 32, Săliştea de Sus

Int. 6: I.P., 2009, aged 66, Ieud

Int. 7: I.S., 2013, aged 39, Spain

Int. 8: I.V., 2005, aged 43, Săliştea de Sus

Int. 9: M.Z., 2008, aged 49, Dragomireşti

Int. 10: S.I., 2001, aged 52, Săliştea de Sus

Int. 11: V.I., 2001, aged 22, Săliştea de Sus 